\title{
Population size, habitat use and movement patterns during the breeding season in a population of Perez's frog (Pelophylax perezi) in central Spain
}

\author{
Gregorio Sánchez-Montes ${ }^{1}$, Iñigo Martínez-Solano ${ }^{2, *}$ \\ ${ }^{1}$ Museo Nacional de Ciencias Naturales, CSIC, Madrid, Spain. \\ ${ }^{2}$ Instituto de Investigación en Recursos Cinegéticos, CSIC-UCLM-JCCM, Ciudad Real, Spain. \\ * Correspondence: Instituto de Investigación en Recursos Cinegéticos (CSIC-UCLM-JCCM), Ronda de Toledo s/n, 13005 Ciudad Real, \\ Spain. Phone: +34926295 450 ext. 6255, Fax: +34926295 451, E-mail: inigomsolano@irec.csic.es
}

Received: 5 July 2011; received in revised form: 10 November 2011; accepted: 10 November 2011.

Information about demography and habitat use is key for the effective management of amphibian populations, because it is the basis for the long-term monitoring of endangered species and provides insights about the processes by which common species thrive in heavily transformed habitats. A capture-mark-recapture study was performed on a population of Perezs frog (Pelophylax perezi) in central Spain. The study area includes three breeding sites at a maximum distance of 700 metres in a straight line. The aim of the study was to obtain information about demographic parameters, habitat use and movement patterns in this locality during the 2010 breeding season. In one of the breeding sites (Laguna de Valdemanco) we estimated a population of 173 frogs: 91 males (95\% confidence interval: 51-130) and 82 females (95\% CI: 21-144). In the second major breeding site, an adult population of 62 males (95\% CI: 42-83) and 17 females (95\% CI: 10-24) was estimated. Areas of activity of 21 frogs captured more than twice, based on calculation of the minimum area polygons defined by their different capture locations, ranged from 1.28 to $2763.75 \mathrm{~m}^{2}$ (median $=97.94 \mathrm{~m}^{2}$ ). All recorded movements took place in the vicinities of the site where the frogs were first captured (mean distance \pm standard deviation $=49 \pm 41 \mathrm{~m}$, maximum distance $=168 \mathrm{~m}$ ), with the exception of a male that moved between two breeding sites 273 metres apart. These preliminary results can be applied to management strategies for this and other co-distributed species.

Key words: amphibians; central Spain; demography; dispersal; habitat use; population size.

Tamaño poblacional, uso del espacio y patrones de movimiento durante el periodo reproductor en una población de rana verde común (Pelophylax perezi) en Espańa central. Los estudios sobre demografía y uso del espacio resultan esenciales para la gestión de poblaciones de anfibios, ya que fundamentan el seguimiento a largo plazo de especies amenazadas y permiten comprender los mecanismos mediante los cuales especies comunes proliferan en medios fuertemente alterados. En este trabajo presentamos resultados de un estudio de captura-marcaje-recaptura en una población de rana verde común (Pelophylax perezi) en España central. El área de estudio alberga tres puntos de reproducción, separados por distancias máximas de 700 metros en línea recta. El objetivo del estudio fue estimar parámetros demográficos y analizar patrones de uso del espacio y movilidad durante la temporada de reproducción en 2010. En uno de los puntos (Laguna de Valdemanco) se estimó una población de 173 ranas: 91 machos (intervalo de confianza al 95\%: 51-130) y 82 hembras (IC 95\%: 21-144). En otro punto de reproducción estimamos una población adulta de 62 machos (IC 95\%: 42-83) y 17 hembras (IC 95\%: 10-24). Se estimaron las áreas de actividad de 21 ejemplares en base al cálculo de los polígonos de área mínima definidos por los puntos de captura, con valores entre 1.28 y $2763.75 \mathrm{~m}^{2}\left(\right.$ mediana $\left.=97.94 \mathrm{~m}^{2}\right)$. Todos los movimientos detectados se produjeron en las inmediaciones del lugar inicial de captura (media: $49 \mathrm{~m}$, desviación estándar: $41 \mathrm{~m}$, distancia máxima: $168 \mathrm{~m}$ ), excepto un macho que se desplazó entre dos puntos de reproducción distantes entre sí $273 \mathrm{~m}$. Estos resultados preliminares son aplicables al diseño de estrategias de gestión para ésta y otras especies codistribuidas.

Key words: anfibios; demografía; dispersión; España central; tamaño poblacional; uso del espacio. 
Several studies have described the spatial organization of different amphibian species as metapopulations (SJÖGREN-GULVE \& RAY, 1996; Marsh \& Trenham, 2001; Green, 2003; but see also SMITH \& GREEN, 2005). Structured this way, amphibian populations can subsist and even thrive in areas under heavy human pressure, like rural areas characterized by a mosaic-like landscape, provided that a wellconnected network, including both aquatic breeding sites and terrestrial habitats, exists (MAZEROlle, 2001; BAUER et al., 2010). A key factor is connectivity, which requires knowledge on the dispersal abilities of the species involved, such that if distances between breeding sites and/or between aquatic and terrestrial habitats exceed certain thresholds, re-colonization dynamics cannot counteract local extinctions, compromising the long-term survival of populations (Sjögren Gulve, 1994; CARLSON \& EDENHAMn, 2000). Thus, information about habitat use and demography is key for the effective management of amphibian populations (WeLlS, 2007). For instance, based on these studies, areas that are important for the connectivity of different population nuclei in a region can be identified and the critical distances above which populations can be considered isolated from a demographic perspective can be assessed (FORTUNA et al., 2006; COMPTON et al., 2007). Detection of demographically isolated populations is crucial, since they are more prone to extinction caused by purely stochastic processes (SjöGren Gulve, 1994; Cushman, 2006).

Several studies have provided data on demographic parameters (ADAMA \& BEAUCHER, 2006; KAYA et al., 2010), spatial movements (SJÖGREN-GULVE, 1998a,b) and habitat use (BLOMQUIST \& HUNTER, 2009) in amphibian populations worldwide (see review in WeLLS, 2007), but data on Iberian amphibians are comparatively scarce (MALKMUS, 1982; Díaz Paniagua \& Rivas, 1987; LizANA et al., 1989; GarCía-PARÍs et al., 2004). Capture-mark-recapture studies require continued, intensive sampling effort through many years, but they can provide very detailed information about the demography of populations, which is a fundamental aspect to take into account for their management (MARSH \& Trenham, 2001; BlackWell et al., 2004; SCHMIDT et al., 2005; ERISMIS, 2011). Most of these studies attempt to understand the basic requirements of endangered species with the aim of designing conservation strategies to avoid their extinction (Richter \& Seigel, 2002; ConRoy \& BroOK, 2003). But a complementary approach to the problem of amphibian declines may involve understanding the processes by which other species maintain positive demographic trends and thrive in the same environments where others disappear.

Perez's frog - Pelophylax perezi (Seoane, 1885 ) - is a good model in this respect. This species is endemic from the Iberian Peninsula and southern France, where it is almost uniformly distributed and locally very abundant and, therefore, it is catalogued as "Least Concern" under the IUCN extinction risk criteria (LLORENTE et al., 2002; BosCH et al., 2008). Although there are some studies about biometry (GOSÁ \& ARIAS, 2009) and population age-structure as assessed by skeletochronology (PATÓN et al., 1991; Esteban et al., 1996), there is no information about their typical home ranges or habitat use and its general biology is poorly known (EGEASERRANO, 2009). In this paper, we present preliminary results about the demography, areas of activity and movement patterns 
during the breeding season of a population of P. perezi in an area in the north of the province of Madrid (central Spain) in 2010. The specific objectives of the study were:

1) To estimate the population size, apparent survival and the probability of recapture of individuals of $P$. perezi in the study area using a capture-mark-recapture method.

2) To record the distances travelled by individuals during the breeding season and to calculate their areas of activity.

3) To investigate possible differences in demographic parameters (population size, apparent survival, probability of recapture) and movement patterns between sexes and breeding sites.

4) To provide biometric (body mass and snoutvent length) data and analyze their relationship with demographic parameters (popula- tion size, apparent survival, probability of recapture), and movement patterns.

\section{Materials AND METHODS}

\section{Study area}

The study area has an extension of $0.5 \mathrm{~km}^{2}$ and is located near the town of Valdemanco, Madrid, $1140 \mathrm{~m}$ above sea level (UTM: $x=30 T 445213 \mathrm{E}, \mathrm{y}=4522623 \mathrm{~N}$, included in the $10 \times 10 \mathrm{~km}$ UTM grid VL42) (Fig. 1). For practical purposes, it was delimited using some of the existing trails, which surround an area with lower cattle pressure (which is, with mining, the main land use in the area) than adjacent lands. There are no artificial barriers potentially affecting amphi-

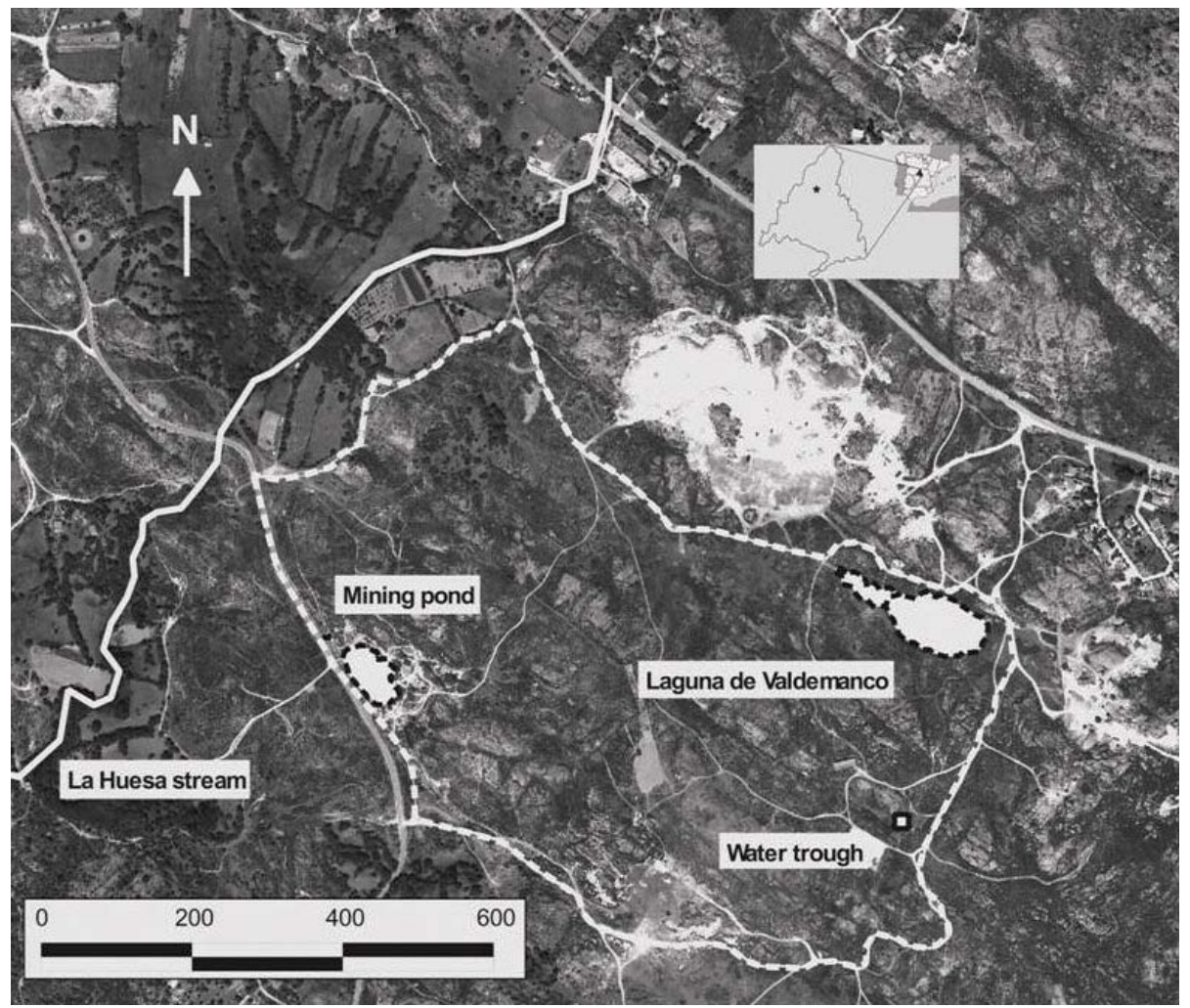

Figure 1: Map of the study area near Valdemanco, in Madrid (central Spain). The inset in the upper right corner shows the location of the study area in the Iberian Peninsula and in the region of Madrid. The trails that delimit the study area are highlighted with a dotted white line. Indicated are the locations of the three main breeding sites: Laguna de Valdemanco, the mining pond and the water trough. 
bian dispersal. The study area includes two main water bodies where a rich amphibian community breeds, including Pleurodeles waltl, Triturus marmoratus, Alytes cisternasii, Pelobates cultripes, Bufo calamita, Hyla arborea and Pelophylax perezi (MARTínez-Solano, 2006). In general, it is a well-preserved area, with occasional minor impacts derived from cattle (grazing, eutrophication) and human activities (land filling, trash dumping, introduction of exotic species).

The largest pond, Laguna de Valdemanco, is an epigenic and semi-permanent aquatic system of $12800 \mathrm{~m}^{2}$ of extension, with a maximum depth of $1 \mathrm{~m}$. It is included in the Catálogo de Embalses y Humedales de la Comunidad de Madrid (COMUNIDAD DE MADRID, 2004). Adjacent meadows are usually flooded during the winter and early spring. Abundant and tall aquatic vegetation dominates in the spring (Carum verticillatum, Juncus acutiflorus, Ranunculus fluitans, Eleocharis palustris). In the north bank there are some willow trees (Salix sp.) and in the vicinities of the pond, the gum rockrose (Cistus ladanifer) predominates.

The other pond is an abandoned mining site between 35 and 55 years old (see satellite images at COMUNIDAD DE MADRID, 2011). It is smaller $\left(2100 \mathrm{~m}^{2}\right)$, but deeper (maximum depth: $1.7 \mathrm{~m}$ ) and with a longer hydroperiod than Laguna de Valdemanco, from which it is separated by 700 metres in a straight line (Fig. 1). The margins of this pond are more abrupt, and aquatic vegetation is less abundant. In the east bank there are some willow trees (Salix sp.) and gum rockroses (Cistus ladanifer). During the course of the present study, we detected the presence of the red swamp crayfish (Procambarus clarkii) in this pond, although densities were low.
Apart from these two ponds, we detected breeding activity of $P$. perezi in a small $(2 \mathrm{~m}$ long, $50 \mathrm{~cm}$ deep) water trough in the study area (Fig. 1). This site presents running water throughout the year, with no vegetation other than green algae, and is $233 \mathrm{~m}$ apart from Laguna de Valdemanco and $706 \mathrm{~m}$ apart from the mining pond (linear distances).

\section{Sampling methods}

In order to monitor the frog population in the study area, we performed night surveys, focused on breeding sites, with all the water surface and shores sampled homogeneously. Frogs were captured by hand or with the help of dip nets. We also surveyed terrestrial habitats, mostly along the trails delimiting the study area, but also covering the rest of the study area in search of adult frogs actively dispersing (in nights with appropriate climatic conditions: warm temperatures, high humidity, little or no wind) or hiding under rocks or other refuges during the day. In all cases, we recorded temperature, number of researchers involved in the surveys and total time spent. Data were obtained from a total of 44 field visits during the period of activity of the frogs (March-October 2010).

The differences in hydroperiod of the ponds conditioned the maximum number of visits in each case. A total of 11 surveys were performed in Laguna de Valdemanco between April $6^{\text {th }}$ (when the first $P$. perezi individuals were detected in the pond after hibernation) and June $11^{\text {th }} 2010$ (when only a few adults remained in the pond, just before it dried up). The mining pond was visited 18 times, starting on May $18^{\text {th }}$ and until October $30^{\text {th, when }}$ only a few isolated puddles remained. The 
water trough was visited five times between July $21^{\text {st }}$ and October $25^{\text {th }}$. The sampling was completed with 10 surveys on terrestrial habitats. The frequency of the visits was irregular, since the goal of the study was to capture and mark as many frogs as possible within a single breeding season, but on average the study area was visited once every five days.

The location of each captured frog was recorded with accuracy equal to or lower than five metres using a Garmin Etrex GPS device (Garmin International Inc., Olathe, Kansas, USA). For all specimens, we recorded sex, snout-vent length (SVL) and body mass (measured with a Pesola MS 1000 scale (Pesola AG, Baar, Switzerland) with a precision of $0.2 \mathrm{~g}$ ). When individuals were captured for the first time, we marked them with an $8 \mathrm{~mm}$ AVID M.U.S.I.C. chip (EzID, Greeley, Colorado, USA) including a unique identity code that was dorsally inserted under the skin using a hypodermic needle (AVID Single Use Disposable Syringe monoject). Chips were read using an AVID Minitracker II RS232 reader device. All specimens were released back in their place of capture after marking.

\section{Biometry}

We tested for differences in body mass and SVL between sexes and between breeding sites (excluding the water trough due to low sample size). In the case of frogs captured more than once, the values recorded in their first capture were used for the analyses. The variable "body mass" did not adjust to a normal distribution, so we used non-parametric tests (MannWhitney's U) to analyze differences in body mass between sites and sexes, whereas parame- tric tests (Student's t) were used to test for differences in SVL, since this variable did adjust to a normal distribution. We also explored the effects of the interaction sex*locality for SVL data. For all analyses, $P$-values $<0.05$ were considered significant.

In recaptured frogs, we also calculated mass variation between the first and the last capture, taking into account the time elapsed between captures (= body mass variation per day). Differences were expressed as a proportion of the body mass at the time of the first capture. We tested for differences between sexes using non-parametric (Mann-Whitney's U) tests, and between breeding sites using parametric (Student's t) tests using SPSS 15.0.

\section{Estimates of demographic parameters}

No dispersal was detected between the two main breeding sites during the activity period in 2010, so in our analyses they were considered as independent, open populations, and population sizes of both sites (Laguna de Valdemanco and the mining pond) were thus estimated separately. The number of captured frogs at the third site (water trough) was too small (see Results), so this site was not included in the analyses.

We used the free software MARK 6.0 (WHITE \& BURNHAM, 1999) to estimate demographic parameters. MARK allows to test the fit of different models to observed data (in this case, the encounter history of each individual), and assess which model (or models) is the best according to the Akaike Information Criterion corrected for finite sample sizes (AICc, AKAIKE, 1974; BURNHAM \& Anderson, 2002). The AICc assigns a score to each model on the basis of the amount 
of variance explained, penalized by the number of parameters in the model. To estimate population sizes, MARK uses the Jolly-Seber method (Jolly, 1965; SEBER, 1965) in the POPAN subroutine (SCHWARZ \& ARNASON, 1996). This method shares the typical assumptions of capture-mark-recapture (CMR) studies in open populations and is based on the estimation of four main parameters: 1) apparent survival of individuals between capture events (phi), 2) probability of capture in each survey (p), 3) rate of entrance of new individuals to the study area between two sampling occasions (pent) and 4) the population size $(\mathrm{N})$. In all cases, $\mathrm{N}$ and the other parameters are treated as dependent variables. We tested different models, analyzing the behaviour of the parameters phi, $\mathrm{p}$ and pent in four different, albeit complementary ways, considering them as: a) constant, b) time-dependent, c) sexdependent and d) time-and-sex-dependent. Estimates for $\mathrm{N}$, phi and $\mathrm{p}$ were calculated for adult frogs along with their 95\% confidence intervals $(95 \% \mathrm{CI})$ for each pond, by averaging the best models. The average of each parameter is calculated as the weighted average of the values estimated by the different models, where each model has a weight inversely proportional to its AICc. We also used MARK 6.0 to test for correlations between population parameters (phi and $\mathrm{p}$ ) and biometric variables (body mass and SVL, separately).

\section{Movement patterns and areas of activity}

The distances covered by each individual captured at least once after the initial capture were calculated using the software ArcGIS 9.2. Additionally, for frogs captured twice or more after their initial capture, areas of activity during the breeding season were estimated as the minimum convex polygon (MCP) defined by their recorded locations (KIE et al., 1996). ArcGIS was also used to calculate the 50, 90 and 95 Kernel areas (i.e. the areas with 50\%, $90 \%$ and $95 \%$ probability of including an individual). Absolute measures of distances covered and areas of activity were standardized with respect to the time interval in which they were recorded (and thus represent daily distances or areas, respectively), in order to 1) allow direct comparison of movements between sexes and to 2) test for possible correlations between movement patterns and biometry (body mass and SVL). These analyses were performed with the software SPSS 15.0 for Windows.

We tested for differences in the variables "mean daily distance" (= mean of the distance values per each elapsed day) and "mean daily area" (= mean of the area of activity values per day) between the two main ponds and between both sexes using non-parametric Mann-Whitney's U tests, since none of them was normally distributed when using all the locations together, nor when the two ponds were analyzed separately. We also used Spearman's correlation coefficient to analyze linear relationships between movement patterns and biometry (body mass and SVL) in all observations pooled together.

\section{RESULTS}

\section{Sampling effort}

Total sampling effort, measured as persons*hours, was 296 (150 at the mining pond, 83 at Laguna de Valdemanco and 63 in diurnal and nocturnal transects along trails). All captured frogs were found at or in the imme- 
diate vicinity of the three breeding sites (the two ponds and the water trough). Day and night surveys in terrestrial habitats were unsuccessful, although we found juveniles and adults of other species, like B. calamita, $H$. arborea and $P$. cultripes.

During the 34 surveys performed at breeding sites, we recorded a number of 207 captures (including recaptures), 94 of them at Laguna de Valdemanco, 111 at the mining pond and two at the water trough. We marked 129 different individuals (73 at Laguna de Valdemanco, 55 at the mining pond and one at the water trough). Mean number of captures per unit of sampling effort was 1.16 per person*hour in Laguna de Valdemanco and 0.74 per person*hour in the mining pond. We marked more males than females or juveniles (78 males: 43 in L. Valdemanco, 34 in the mining pond and one in the water trough; 42 females: 30 in L. Valdemanco and 12 in the mining pond; and nine juveniles: all of them at the mining pond).

Recapture rates per individual were in general low: $62.79 \%$ of sampled individuals were captured only once, $20.93 \%$ twice, $10.08 \%$ three times, $5.43 \%$ four times and a single individual was captured five times. Recapture rates were significantly lower in Laguna de Valdemanco $($ mean $=0.30 ; \mathrm{SD}=0.57$ ) than in the mining pond (mean $=1.02 ; \mathrm{SD}=$ 1.15) (Mann-Whitney's $U: U=1322.0 ; \mathrm{N}$ (L. Valdemanco $)=73, \mathrm{~N}$ (mining pond $)=55$; $P<0.001)$. Recapture rates in juveniles (mean $=0.33$; SD $=0.71)$ were non-significantly lower than in adults (mean adult males = $0.63, \mathrm{SD}=0.87$; mean adult females $=0.62$, $\mathrm{SD}=1.08)$ (Kruskal-Wallis's $\mathrm{K}: \mathrm{H}_{2}=6.213$; $P=0.469)$.

\section{Biometry}

Body mass and SVL were strongly correlated (Spearman's Rho: Rho = 0.970; N = 124; $P<0.001)$. Very significant biometric differences were found between sexes, with females being significantly larger than males in body mass (median / inter-quartile amplitude: males = $19.0 / 10.5 \mathrm{~g}$, females = 50.2 / $25.4 \mathrm{~g}$; Mann-Whitney's $\mathrm{U}: \mathrm{U}=170.5$; $\mathrm{N}$ : males $=73$, females $=42 ; P<0.001)$ and SVL (mean \pm SD: males $=63.3 \pm 8.4 \mathrm{~mm}$, females $=82.02 \pm 10.02$ mm; Student's t: $\left.\mathrm{t}_{118}=-10.769 ; P<0.001\right)$. No differences between individuals of the same sex from Laguna the Valdemanco and the mining pond were found in body mass (males: median / inter-quartile amplitude: L. Valdemanco $=19.0 / 10.4 \mathrm{~g}$, mining pond = 19.0 / 13.1 g; Mann-Whitney's U: U = 613.5; $\mathrm{N}$ : L. Valdemanco $=39$, mining pond $=33$; $P=0.735$. Females: median / inter-quartile amplitude: L. Valdemanco $=51.2 / 27 \mathrm{~g}$, mining pond $=42.1 / 22.4 \mathrm{~g}$; MannWhitney's $U: U=143.0 ; \mathrm{N}: \mathrm{L}$. Valdemanco $=30$, mining pond $=12 ; P=0.314$ ) or SVL (males: mean \pm SD: L. Valdemanco $=62.0 \pm 6.7 \mathrm{~mm}$, mining pond $=64.9 \pm 10.1 \mathrm{~mm}$; Student's t: $\mathrm{t}_{75}=-1.025 ; P=0.309$. Females: mean $\pm \mathrm{SD}$ : L. Valdemanco $=81.8 \pm 10.7 \mathrm{~mm}$, mining pond $=82.5 \pm 8.6 \mathrm{~mm}$; Student's $\mathrm{t}$ : $\mathrm{t}_{40}=-0.193$; $P=0.848$ ). We found no significant effect of the interaction sex*locality in SVL (data not shown).

Calculation of body mass differences relative to initial body mass in individuals captured more than once revealed that females suffered in general stronger losses. However, gains of more than $20 \%$ with respect to body mass at the time of first capture were also recorded in individuals from both sexes (Fig. 2). When differences relative to initial body mass 


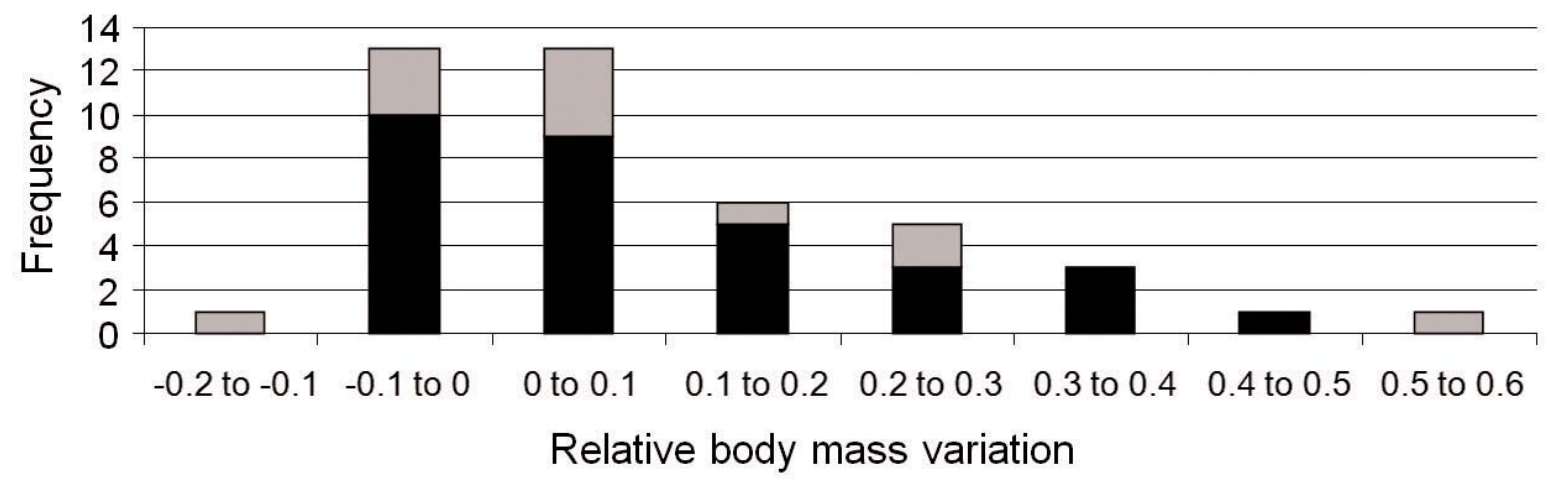

Figure 2: Frequency histogram of body mass differences relative to body mass at initial capture for males (dark bars) and females (grey bars). Values are expressed as proportions.

were time-standardized, no differences between sexes were found (median / inter-quartile amplitude: males $=0.0017 / 0.0117 \mathrm{day}^{-1}$, females $=0.0031 / 0.0131 \mathrm{day}^{1} ;$ MannWhitney's $\mathrm{U}: \mathrm{U}=163.00 ; \mathrm{N}$ (males) $=31, \mathrm{~N}$ (females) $=12 ; P=0.547)$. However, whereas adult frogs in Laguna de Valdemanco experienced losses in body mass throughout the study, frogs from the mining pond showed the opposite trend (mean \pm SD: adults (L. Valdemanco): $-0.0038 \pm 0.0085$ day $^{1}$, adults (mining pond): $0.0066 \pm 0.0067$ day $^{-1}$; Student's t: $\left.\mathrm{t}_{41}=-4.492 ; P<0.001\right)$. There was no significant effect of the interaction between sex and locality for the variable "body mass variation per day" (data not shown).

\section{Estimates of demographic parameters}

According to MARK results, the best models were those that assume that the probability of entrance (pent) is time-dependent, whereas apparent survival (phi) and probability of capture (p) are either constant or sexdependent (Table 1). More complex models were penalized due to over-parameterization. In order to obtain accurate estimates for the parameters of interest, a weighted averaging of the best models was performed according to their AICc. Apparent survival (phi) was high in both water bodies and there were only slight differences between males and females (estimated phi $(95 \% \mathrm{CI})$ : males (L. Valdemanco $)=0.912(0.860-0.946)$; females (L. Valdemanco $)=0.932(0.850-0.971)$; males (mining pond $)=0.978(0.968-0.985)$; females (mining pond) $=0.977(0.964-0.985)$ ) On the other hand, although males were similarly "detectable" in both ponds, females were easier to capture in the mining pond than in Laguna de Valdemanco (estimated $\mathrm{p}$ (95\% CI): males (L. Valdemanco) $=0.253$ $(0.135-0.423)$; females $(\mathrm{L}$. Valdemanco) $=0.169$

Table 1: Model selection. Scores of the Corrected Akaike Information Criterion (AICc), model weights and number of parameters for preferred models at each breeding site. $g=$ gender-dependent, $t=$ timedependent, and.$=$ constant.

\begin{tabular}{|c|c|c|c|c|}
\hline Pond & Model name & $\mathrm{AICc}$ & $\begin{array}{l}\text { AICc } \\
\text { Weight }\end{array}$ & $\begin{array}{l}\text { Num. of } \\
\text { params. }\end{array}$ \\
\hline Laguna de & $\operatorname{phi}() p.(.) \operatorname{pent}(\mathrm{t})$ & 243.2289 & 0.35544 & 13 \\
\hline \multirow[t]{3}{*}{ Valdemanco } & phi $(g) p(g) \operatorname{pent}(t)$ & 243.2908 & 0.34461 & 15 \\
\hline & phi(.)p(g)pent $(\mathrm{t})$ & 244.4822 & 0.18994 & 14 \\
\hline & phi(g)p(.)pent(t) & 245.6365 & 0.10665 & 14 \\
\hline \multirow[t]{3}{*}{ Mining pond } & $\operatorname{phi}() p.(g) \operatorname{pent}(\mathrm{t})$ & 417.2786 & 0.68731 & 21 \\
\hline & phi $(g) p(g)$ pent $(t)$ & 420.4249 & 0.14254 & 22 \\
\hline & phi(.)p(.)pent $(\mathrm{t})$ & 420.4340 & 0.14189 & 20 \\
\hline
\end{tabular}


(0.060-0.392); males $($ mining pond $)=0.225$

$(0.153-0.318)$; females (mining pond $)=0.383$ (0.233-0.559)).

We found slight differences in the relationship between demographic and biometric variables as a function of site or sex. In Laguna de Valdemanco, the best model for estimating male population size selected by MARK included a positive linear relationship between apparent survival and SVL, whereas the probability of capture was independent of size (body mass and SVL). For females, however, there was no significant relationship between demographic and biometric variables. Similarly, in the mining pond, the best models assumed that there was no relationship between demographic and biometric variables ( $\mathrm{phi}$ and $\mathrm{p}$ were constant for both sexes).

Population size $(\mathrm{N})$ was higher in Laguna de Valdemanco (mean of 173 adult frogs) than in the mining pond (79 adult frogs), but the $95 \%$ CI was narrower in the latter, as a result of the higher recapture rates in this site (Table 2). There were differences in sex-ratio between ponds, with proportions near 1:1 in Laguna de Valdemanco, but biased toward males in the mining pond (4:1).

Table 2: Estimates of population sizes $(\mathrm{N})$ and their $95 \%$ confidence interval $(95 \%$ CI) for adults of both sexes at Laguna de Valdemanco and at the mining pond.

\begin{tabular}{lccc}
\hline \hline Breeding site & Sex & N & 95\% CI \\
\hline Laguna de & Males & 91 & $51-130$ \\
Valdemanco & Females & 82 & $21-144$ \\
& & & \\
Mining pond & Males & 62 & $42-83$ \\
& Females & 17 & $10-24$ \\
\hline
\end{tabular}

\section{Movement patterns and areas of activity}

We recorded a total of 48 distances between captures, 19 in Laguna de Valdemanco (14 males and five females, including the longest distance recorded, an adult male that dispersed from the pond to the water trough) and 29 in the mining pond (19 males, eight females and two juveniles). Juveniles were excluded from subsequent analyses due to the low number of observations. Since a minimum number of three locations are required to estimate the area of activity for a given individual, our dataset was reduced to samples of 21 individuals, two in Laguna de Valdemanco and 19 in the mining pond.

Mean distances covered by adult frogs during the breeding season were around 50 $\mathrm{m}$ (mean distance $\pm \mathrm{SD}=49 \pm 41 \mathrm{~m}$, Fig. 3). The longest distance overall was covered by a male that was initially captured at Laguna de Valdemanco and recaptured four months later at the water trough, which is $273 \mathrm{~m}$ apart. The largest estimated area of activity $\left(2763.75 \mathrm{~m}^{2}\right)$ corresponded to a male that was recaptured three times after the initial capture at Laguna de Valdemanco in a time lapse of 17 days, but median values were much smaller (median / inter-quartile amplitude: $97.94 / 199 \mathrm{~m}^{2}$, Fig. 4).

We found no significant differences between sexes in time-standardized distances, either in the combined dataset (median / inter-quartile amplitude: males $=1.563 /$ $7.116 \mathrm{~m} \cdot$ day $^{-1}$, females $=2.048 / 3.259 \mathrm{~m}$. day $^{1}$; Mann-Whitney's $\mathrm{U}: \mathrm{U}=213.00 ; \mathrm{N}$ : males $=33$, females $=13 ; P=0.971$ ) or when both ponds were analyzed separately (Laguna de Valdemanco: median / inter-quartile amplitude: males $=8.257 / 18.078 \mathrm{~m} \cdot$ day $^{-1}$, 


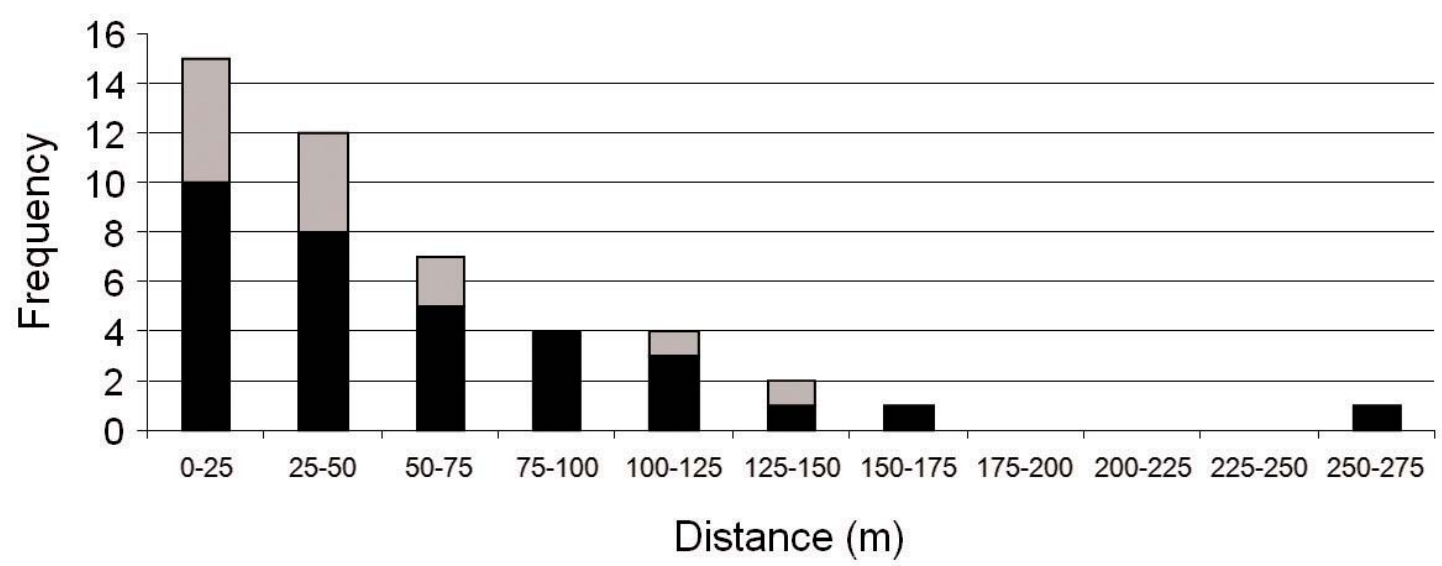

Figure 3: Frequency histogram of absolute distances between captures of males (dark bars) and females (grey bars) at the study area.

females $=4.718 / 5.867 \mathrm{~m} \cdot$ day $^{1} ;$ MannWhitney's $\mathrm{U}: \mathrm{U}=19.00 ; \mathrm{N}$ : males $=14$, females $=5 ; P=0.156$. Mining pond: median / inter-quartile amplitude: males $=$ $1.074 / 0.845 \mathrm{~m} \cdot$ day $^{-1}$, females $=1.701 /$ $1.659 \mathrm{~m} \cdot$ day $^{1}$; Mann-Whitney's $\mathrm{U}: \mathrm{U}=52.00$; $\mathrm{N}$ : males $=19$, females $=8 ; P=0.217)$. Timestandardized distances recorded in Laguna de Valdemanco were significantly larger than those recorded in the mining pond for males (Mann-Whitney's U: U $=46.00 ; \mathrm{N}: \mathrm{L}$. Valdemanco $=14$, mining pond $=19 ; P=0.001$ ) but not for females (Mann-Whitney's $U$ : $U$ = 13.00; N: L. Valdemanco $=5$, mining pond $=8$; $P=0.354)$.

Due to the low number of observations available for Laguna de Valdemanco, we did not test for differences in areas of activity across sites or between sexes within this site. On the other hand, there were no significant differences between time-standardized areas of activity in males and females in the mining pond (median / inter-quartile amplitude: males $=4.618 / 4.95 \mathrm{~m}^{2} \cdot$ day $^{1}$, females $=3.039$ $19.636 \mathrm{~m}^{2} \cdot$ day $^{1}$; Mann-Whitney's $\mathrm{U}: \mathrm{U}=34.00$; $\mathrm{N}$ : males $=11$, females $=7 ; P=0.724)$. Finally, no significant correlation was found between time-standardized distances or areas and biometric variables (Distance-body mass: Spearman's Rho: $\mathrm{Rho}=-0.05 ; \mathrm{N}=44 ; P=0.745$. Distance-SVL: Rho $=-0.078 ; \mathrm{N}=46 ; P=0.607$. Area-body mass: Rho $=0.041 ; \mathrm{N}=20 ; P=0.862$. Area-SVL: Rho $=-0.051 ; \mathrm{N}=20 ; P=0.830$ ).

\section{DisCUSSION}

The population of $P$. perezi at Laguna de Valdemanco is almost twice as big as that in the mining pond, although uncertainty in population size estimates is also larger in the former. In spite of this, the difference in estimated population sizes is not as large as could be expected given their relative areas (Laguna de Valdemanco has six times more water surface than the mining pond). Differences in hydroperiod may help explain this pattern, since Laguna de Valdemanco dries up in early or mid summer, whereas the mining pond maintains water throughout most or all the summer, and differences in hydroperiods obviously represent a limiting factor for water dependent amphibians, especially for species with longer tadpole stages, like P. perezi (RICHTER-BOIX et al., 2006).

Sex ratio is close to 1:1 in Laguna de Valdemanco, in contrast with the results in the mining pond (4:1 in favour of males). 


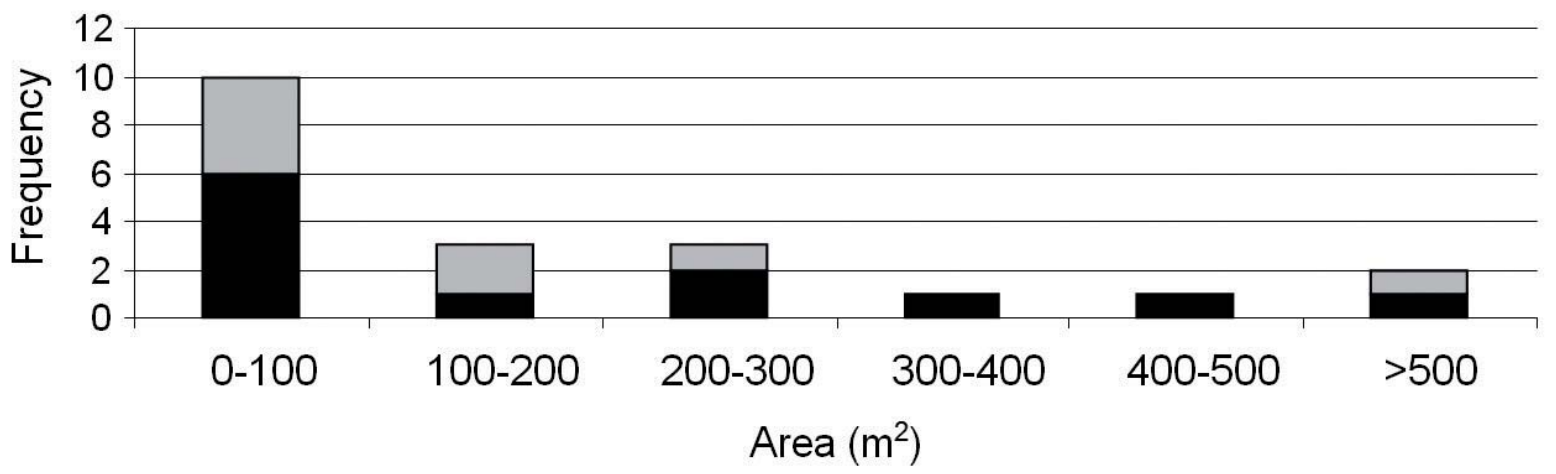

Figure 4: Frequency histogram of estimated areas of activity of males (dark bars) and females (grey bars) at the study area.

This result may be an artefact related to low recapture rates in the former site, so these differences must be taken with caution until new data from subsequent breeding seasons are available. With respect to biometry, our results are in agreement with those summarized by EgEA-SERRANO (2009) and in contrast with REAL \& ANTÚNEZ (1991). Size differences between sexes, with females being significantly larger than males, were consistent across breeding sites. Body mass variations in both sexes are probably related to breeding activity, with sharp losses following egg laying in females and mostly increases in males, which present an intense feeding activity during the breeding season (REAL \& ANTÚNEZ, 1991). However, these results have to be taken with caution, since our procedure overlooked a potential source of significant variation in mass estimates: the water stored in the bladder of adult frogs, which can represent an important percentage of the total body mass. Regarding habitat use, both sexes seem to occupy all available space along the shores, although females seemed to use preferentially more protected areas, like those with denser vegetation (mainly Salix sp., Fig. 5), although this hypothesis has not been thoroughly explored yet.
We did not detect any individual movement between the main breeding sites in our study area (with the single exception highlighted above, the male moving from Laguna de Valdemanco to the water trough), despite the fact that one of the ponds (Laguna de Valdemanco) dried up one month earlier than the other. This suggests high fidelity of adults to their breeding sites, which could be chosen primarily during their post-metamorphic dispersal stage, as documented in other

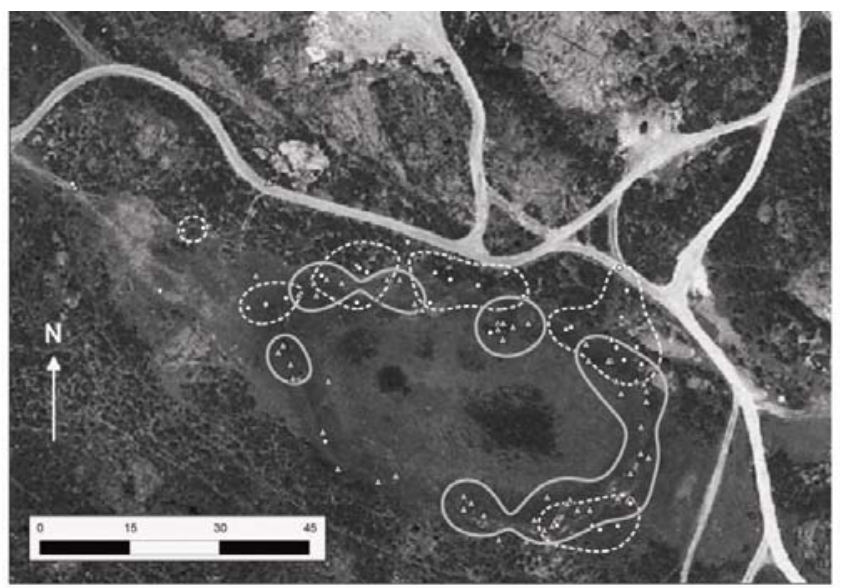

Figure 5: Map showing all recorded locations of P. perezi at Laguna de Valdemanco (males = grey triangles, females $=$ white circles) along with their corresponding Kernel 50 areas (males $=$ continuous grey lines, females $=$ dotted white lines). Females were mostly captured along the north bank, where there are some willow trees (Salix sp.) providing refuge. Males, in contrast, are more widely distributed and tend to occupy all the available space. 
European species of green waterfrogs (SJÖGREN GULVE, 1994). As a consequence, the disappearance of a breeding site may have a stronger impact in populations of $P$. perezi than in other, more vagile species (for example, in our study area, Hyla arborea, I. Martínez-Solano, J. Gutiérrez \& G. SánchezMontes, unpublished data), at least in the short term. Nonetheless, our study covered a single breeding season, and in the long term some degree of interconnectedness between breeding sites is expected, especially by means of recently metamorphosed or immature individuals. Further monitoring of this population will help address this question, with the aid of genetic tools that can identify "cryptic" dispersal events (JEHLE et al., 2005; ZAMUDiO \& WieczoreK, 2007). At the moment, our observations (the single dispersal event from Laguna de Valdemanco to the water trough as well as additional observations during the 2011 breeding season) suggest that the three breeding sites in the study area are connected by low frequency migratory events.

The frequency histogram of the distances covered by individuals of $P$. perezi shows the typical leptokurtic (asymmetric and positive) pattern, with most observations representing short distances $(82.6 \%<100 \mathrm{~m})$ but also a few observations involving longer distances (Fig. 3). The longest displacement of an individual of $P$. perezi recorded in this study was by a male from Laguna de Valdemanco that was recaptured, four months after its first capture, in the water trough. These sites are not connected by superficial water currents or intermediate puddles, and the linear distance of 273 metres is probably an underestimate of the actual distance covered during dispersal, which might have followed some of the exis- ting trails, but in any case involved crossing to some extent a dense vegetal matrix dominated by Cistus ladanifer. On the other hand, the relative importance of the water trough site for the overall breeding success of $P$. perezi in the study area is unclear (vs., for instance, its relevance as a foraging area). EGEA-SERRANO et al. (2005) documented that these small, artificial breeding sites were usually negatively selected by the species against other alternatives like ponds or reservoirs, but our results suggest they may be important in a metapopulation context. In our study area, this source of permanent water throughout the year allows hibernating tadpoles to metamorphose during the next breeding season with larger body sizes (authors' personal observations), which may be advantageous from a fitness perspective (Berven \& Gill, 1983). Parentage analysis using multilocus genotypes from samples of tadpoles and adults in all breeding sites will help clarify the role of this site in the breeding success of $P$. perezi in the study area.

With the noted exception, all recorded movements took place within each major breeding site. Laguna de Valdemanco, the larger pond, offers more water surface than the mining pond, and correspondingly, resident frogs present longer within-pond distances between captures. In general, males seem to move more than females (Fig. 3), but some females also have large areas of activity (Fig. 4), although differences are not statistically significant. In any case, our calculations, with $50 \%$ of estimated areas below or equal $100 \mathrm{~m}^{2}$ (Fig. 4), are probably underestimations of the actual areas of activity and home ranges in this species, and while this represents a valuable first approximation, more data, based on subsequent monitoring, will be required. 
Our study presents the first data on movement patterns in P. perezi. We found a typical pattern, with high frequency of low distance movements within breeding ponds and very low frequency of long dispersal events (Fig. 3), suggesting long-term interconnectedness between breeding sites in the study area. Males and females of $P$. perezi seem to have similar areas of activity during the breeding season, mainly restricted to the ponds where they breed (Fig. 4). These data, while still preliminary, will be important in understanding finescale population dynamics in this species, including regional patterns of connectivity between breeding sites.

\section{Acknowledgement}

The help of Garazi Rodríguez was key throughout the study. Thanks as well to Juan Zorrilla and José Serrano for their orientation and to every person who collaborated in the fieldwork: Esperanza and Jaime Iranzo, Ignacio Urbán, Fernando A. Fernández, Jorge Gutiérrez, Jaime Pérez, Antonio Carvajal, Ernesto Recuero, Cristina Grande, Carlos Pedraza, Daniele Salvi and Alfredo Ortega and Javier Castro (Agentes Forestales Comarca V, Torrelaguna). A. Montori and two anonymous reviewers provided useful comments on the manuscript. Legal permits for conducting fieldwork were provided by Consejería de Medio Ambiente, Comunidad de Madrid. This study was funded by project CGL2008-04271-C02-01-BOS (Ministerio de Ciencia e Innovación, Spain, PI: I. Martínez-Solano). Legal regulations and ethical considerations related to work with live animals were strictly followed during the course of this study.

\section{REFERENCES}

Adama, D.B. \& BeAucher, M.A. (2006). Population Monitoring and Recovery of the Northern Leopard Frog (Rana pipiens) in Southeast British Columbia. Columbia Basin Fish and Wildlife Compensation Program, Nelson, British Columbia, Canada.

AKAIKE, H. (1974). A new look at the statistical model identification. IEEE Transactions on Automatic Control 19: 716-723.

Bauer, D.M.; Paton, P.W.C. \& Swallow, S.K. (2010). Are wetland regulations cost effective for species protection? A case study of amphibian metapopulations. Ecological Applications 20: 798-815.

Berven, K.A. \& Gill, D.E. (1983). Interpreting geographic variation in lifehistory traits. American Zoologist 23: 85-97.

Blackwell, E.A.; Cline, G.R. \& Marion, K.R. (2004). Annual variation in population estimators for a southern population of Ambystoma maculatum. Herpetologica 60: 304-311.

Blomquist, S.M. \& Hunter, JR., M.L. (2009). A multi-scale assessment of habitat selection and movement patterns by Northern leopard frogs (Lithobates [Rana] pipiens) in a managed forest. Herpetological Conservation and Biology 4: 142-160.

Bosch, J.; Tejedo, M.; Beja, P.; MartínezSolano, I.; Salvador, A.; García-París, M.; Recuero Gil, E. \& Beebee, T.J.C. (2008). Pelophylax perezi, In IUCN (2010) The IUCN Red List of Threatened Species, $v$. 2010.4. International Union for Nature Conservation and Natural Resources, Gland, Switzerland. Available at http://www.iucnredlist.org/. Retrieved on 11/07/2011. 
Burnham, K.P. \& ANDERSON, D.R. (2002). Model Selection and Multimodel inference: $A$ Practical Information-Theoretic Approach, $2^{\text {nd }}$ ed. Springer, New York.

CARLSON, A. \& EDENHAMn, P. (2000). Extinction dynamics and the regional persistence of a tree frog metapopulation. Proceedings of the Royal Society B 267: 1311-1313.

COMPTON, B.W.; McGarigal, K.; Cushman, S.A. \& Gamble, L.R. (2007). A resistant-kernel model of connectivity for amphibians that breed in vernal pools. Conservation Biology 21: 788-799.

COMUNIDAD DE MADRID (2004). Revisión del Catálogo de Embalses y Humedales de la Comunidad de Madrid (Sección Humedales). Consejería de Medio Ambiente y Ordenación del Territorio, Comunidad de Madrid, Madrid.

Comunidad de MAdrid (2011). Visor de Cartografía Territorial Interactiva. Dirección General de Urbanismo y Estrategia Territorial, Consejería de Medio Ambiente, Vivienda y Ordenación del Territorio, Comunidad de Madrid, Madrid. Available at http://www.madrid.org/cartografia/planea/. Retrieved on 11/07/2011.

Conroy, S.D.S. \& Brook, B.W. (2003). Demographic sensitivity and persistence of the threatened white- and orangebellied frogs of Western Australia. Population Ecology 45: 105-114.

Cushman, S.A. (2006). Effects of habitat loss and fragmentation on amphibians: A review and prospectus. Biological Conservation 128: 231-240.

Díaz Paniagua, C. \& Rivas, R. (1987). Datos sobre actividad de anfibios y pequeños reptiles de Doñana (Huelva, España). Mediterranea 9: 15-27.
Egea-Serrano, A. (2009). Rana común Pelophylax perezi (López Seoane, 1885), In A. Salvador \& I. Martínez-Solano (eds.) Enciclopedia Virtual de los Vertebrados Españoles. Museo Nacional de Ciencias Naturales, Madrid. Available at http://www.vertebradosibericos.org/. Retrieved on 11/07/2011.

Egea-Serrano, A.; Oliva-Paterna, F.J. \& Torralva, M. (2005). Selección de hábitat reproductor por Rana perezi Seoane, 1885 en el N.O. de la Región de Murcia (S.E. Península Ibérica). Revista Española de Herpetología 19: 113-125.

ERISMIS, U.C. (2011). Abundance, demography and population structure of Pelophylax ridibundus (Anura: Ranidae) in 26-August National Park (Turkey). NorthWestern Journal of Zoology 7: 5-16.

Esteban, M.; García-París, M. \& Castanet, J. (1996). Use of bone histology in estimating the age of frogs (Rana perezi) from a warm temperate climate area. Canadian Journal of Zoology 74: 1914-1921.

Fortuna, M.A.; Gómez-Rodríguez, C. \& BASCOMPTE, J. (2006). Spatial network structure and amphibian persistence in stochastic environments. Proceedings of the Royal Society B 273: 1429-1434.

García-París, M.; Montori, A. \& Herrero, P. (2004). Amphibia. Lissamphibia. Series: Fauna Ibérica, vol. 24 (M.A. Ramos, coord.) Museo Nacional de Ciencias Naturales, Madrid.

Gosá, A. \& Arias, A. (2009). Estado de las poblaciones de anfibios en un parque urbano de Pamplona. Munibe 57: 169-183.

GreEn, D.M. (2003). The ecology of extinction: population fluctuation and decline in amphibians. Biological Conservation 111: 331-343. 
Jehle, R.; Wilson, G.A.; Arntzen, J.W. \& BuRKE, T. (2005). Contemporary gene flow and the spatio-temporal genetic structure of subdivided newt populations (Triturus cristatus, T. marmoratus). Journal of Evolutionary Biology 18: 619-628.

JolLY, G.M. (1965). Explicit estimates from capture-recapture data with both death and immigration-stochastic model. Biometrika 52: 225-247.

Kaya, U.; BaşKale, E.; ÇEVIK, I.E.; Kumlutaş, Y. \& Olgun, K. (2010). Population sizes of Taurus frog, Rana holt$z i$, in two different localities, Karagöl and Eğrigöl: new estimations, decline and a warning for their conservation. Russian Journal of Herpetology 17: 247-250.

Kie, J.G.; Baldwin, J.A. \& Evans, C.J. (1996). CALHOME: a program for estimating animal home ranges. Wildlife Society Bulletin 24: 342-344.

Lizana, M.; Ciudad, M.J. \& PérezMellado, V. (1989). Actividad, reproducción y uso del espacio en una comunidad de anfibios. Treballs de la Societat Catalana d'Ictiologia i Herpetología 2: 92-127.

Llorente, G.A.; Montori, A.; Carretero, M.A. \& SANTOS, X. (2002). Rana perezi Seoane 1885. Rana común, In J.M. Pleguezuelos, R. Márquez \& M. Lizana (eds.) Atlas y Libro Rojo de los Anfibios y Reptiles de España. Dirección General de la Conservación de la Naturaleza - Asociación Herpetológica Española, Madrid, pp. 126-128.

MALKMUS, R. (1982). Beitrag zur verbreitung der amphibien und reptilien in Portugal. Salamandra 18: 218-299.

Marsh, D.M. \& Trenham, P.C. (2001). Metapopulation dynamics and amphibian conservation. Conservation Biology 15: 40-49.
Martínez-Solano, I. (2006). Atlas de distribución y estado de conservación de los anfibios de la Comunidad de Madrid. Graellsia 62 (número extraordinario): 253-291.

Mazerolle, M.J. (2001). Amphibian activity, movement patterns, and body size in fragmented peat bogs. Journal of Herpetology 35: 13-20.

Patón, D.; Juarranz, A.; Sequeros, E.; Pérez-Campo, R.; López-Torres, M. \& Barja de Quiroga, G. (1991). Seasonal age and sex structure of Rana perezi assessed by skeletochronology. Journal of Herpetology 25: 389-394.

ReAl, R. \& Antúnez, A. (1991). Análisis e interpretación de las dimorfometrías en una población de Rana perezi. Anales de Biología 17: 63-69.

Richter, S.C. \& Seigel, R.A. (2002). Annual variation in the population ecology of the endangered gopher frog, Rana sevosa Goin and Netting. Copeia 2002: 962-972.

Richter-Boix, A.; Llorente, G.A. \& Montori, A. (2006). Breeding phenology of an amphibian community in a Mediterranean area. Amphibia-Reptilia 27: 544-549.

SchmidT, B.R.; Feldmann, R. \& Schaub, M. (2005). Demographic processes underlying population growth and decline in Salamandra salamandra. Conservation Biology 19: 1149-1156.

SCHWARZ, C.J. \& ARNASON, A.N. (1996). A general methodology for the analysis of capture-recapture experiments in open populations. Biometrics 52: 860-873.

SEBER, G.A.F. (1965). A note on the multiplerecapture census. Biometrika 52: 249-259.

SjÖGREN GulVE, P. (1994). Distribution and extinction patterns within a northern 
metapopulation of the pool frog, Rana lessonae. Ecology 75: 1357-1367.

SJÖGREN-Gulve, P. (1998a). Spatial movement patterns in frogs: Target-oriented dispersal in the pool frog, Rana lessonae. Ecoscience 5: 31-38.

Sjögren-Gulve, P. (1998b). Spatial movement patterns in frogs: Differences between three Rana species. Ecoscience 5: 148-155.

Sjögren-Gulve, P. \& RaY, C. (1996). Using logistic regression to model metapopulation dynamics: large-scale forestry extirpates the pool frog, In D.R. McCullough (ed.) Metapopulations and Wildlife Conservation. Island Press, Washington, D.C., pp. 111-139. Smith, M.A. \& GREen, D.M. (2005).
Dispersal and the metapopulation paradigm in amphibian ecology and conservation: are all amphibian populations metapopulations? Ecography 28: 110-128.

WelLs, K.D. (2007). The Ecology and Behaviour of Amphibians. The University of Chicago Press, Chicago.

White, G.C. \& Burnham, K.P. (1999). Program MARK: survival estimation from populations of marked animals. Bird Study 46: S120-S139.

Zamudio, K.R. \& WieczOreK, A.M. (2007). Fine-scale spatial genetic structure and dispersal among spotted salamander (Ambystoma maculatum) breeding populations. Molecular Ecology 16: 257-274. 